\title{
The Effect Of Competency, Independence, Ethics Auditor And Professionalism To The Audit Quality And Emotional Intelligence As A Variable Of Moderation
}

\author{
Yeni Kumalasari ${ }^{1}$, Muhaimin Dimyati ${ }^{2}$, Ratih Rachmawati ${ }^{3}$ \\ Student STIE Mandala Jember ${ }^{1}$, Lecturer, STIE Mandala Jember ${ }^{2,3}$ \\ Email:dimyati@stie-mandala.ac.id²
}

\begin{abstract}
This study aims to determine the competence, independence, ethics of auditors and professionalism on audit quality and emotional intelligence as a moderation variable. (1) To obtain empirical evidence and analyze about the influence of competence, independence, auditor ethics, professionalism simultaneously on audit quality. (2) To obtain empirical evidence and analyze about the influence of competence, independence, auditor ethics, partially on audit quality. (3) To obtain empirical evidence and analyze the effect of emotional intelligence on the relationship between competence, independence, auditor ethics, professionalism on audit quality. This study uses moderate regression analysis method using SPSS Windows 22. The results in this study indicate that Competence has no effect on audit quality, Independence has an effect on audit quality, Auditor Ethics does not affect audit quality and Professionalism does not affect audit quality, Emotional Intelligence Relationship between Competence, Independence, Auditor Ethics and Professionalism to Quality audit. An independent auditor will provide a tangible assessment of the financial statements, without any burden to any party, so the resulting judgment will reflect the actual conditions of the client being examined.
\end{abstract}

Keywords: Auditor Ethics, Professionalism, Emotional Intelligence, Audit Quality

\section{INTRODUCTION}

In some cases, often the management in practice manipulates their financial statements so that their performance looks good in the eyes of stakeholders and other investors so they are 
interested in investing in the company. This of course will result in the resulting financial statements not in accordance with the actual conditions and will mislead investors, while investors want financial reports that are in accordance with the actual conditions of the company they have financed. So that to increase the company's creadiability in producing relevant and reliable financial reports, one of the policies that is often taken is by conducting audits of company financial reports by competent and independent parties, namely public accountants. The amount of trust from users of public accountants' financial statements requires public accountants to pay attention to the quality of their audits. Ironically, the great trust of users of financial statements to public accountants is often injured by a lot of scandals, for example the disclosure of accounting scandals in large companies involving the public accounting profession, such as KAP Arthur Andersen in the Enron Corporation case has injured public trust in financial reports. auditing and public accounting profession. To restore public trust, public accountants must be able to improve and improve the quality of the audit services provided. According to Sholawatun (2015) good audit quality will produce an audit report that is able to present findings and report truthfully about the financial condition of its clients, including if there is a violation of the client's accounting system.

Auditor competence is an auditor with sufficient and explicit knowledge and experience to carry out an audit objectively, carefully and thoroughly. From this definition, the auditor must have the ability to understand the criteria used and be competent in determining the type and amount of evidence to produce appropriate conclusions after evaluating the evidence.

According to Alvin A. Arens et al, (2012: 23) the value of auditing is highly dependent on public perceptions of auditor independence. Independence is a mental attitude that is free from influence, is not controlled by other parties, and is not dependent on other parties. Independence also means the existence of honest, objective, impartial considerations within the auditor in formulating and expressing his opinion in the auditor in considering facts.

According to Prof. Dr. Abdul Halim (2015: 21) The principles of professional ethics in the code of ethics in the Indonesian Accountants Association state that professional recognition of its responsibilities to the public, accountants, and colleagues. This principle integrates members in fulfilling their professional responsibilities and forms the basis of ethical behavior and professional behavior. 
From the previous explanation, the main problem in this study is whether emotional intelligence is able to moderate the influence of competence, independence, auditor ethics and professionalism on audit quality..

\section{RESEARCH METHODS}

\section{Object of research}

The object used in this study is a public accounting firm in the Surabaya area. The object of this research is taken from a public accounting firm that meets the criteria for sampling.

\section{Population and Sample}

The population is a collection of members of the object under study. The population in this study is a public accounting firm in the Surabaya area. The sample is a group of some members of the object under study. The sampling technique used in this study is purposive sampling, namely the sample is selected using consideration with criteria (Sugiyono, 2010: 183). The criteria used in this study are:

a. Public accounting firm registered in the Surabaya area, which is certified and registered with the financial services authority in 2017.

b. KAP who are willing to be examined.

c. Respondent data studied were available.

\section{Operational Definition of Variables}

The independent variables used in this study are:

\section{Competence}

Competence describes auditors as having adequate education and experience in auditing and accounting. Competency variables are measured using seven questions that describe formal education knowledge that has been taken, knowledge and training, length of work at KAP, knowledge of the client's company conditions, knowledge of the type of client industry, communication with clients.

Independence

Independence describes the mental attitude of auditors who are not easily influenced in carrying out audit tasks. The independence variable is measured using six questions that describe the disclosure of client fraud, provision of non-audit services, length of relationship with clients, the amount of audit fees. 


\section{Auditor Ethics}

Auditor ethics describes the attitudes and morals of auditors that are guided by established rules. Auditor ethics variables are measured using six questions that describe compliance with audit standards. Each of these statement items is measured using a Likert Li scale

\section{Professionalism}

Professionalism describes the professional attitude of auditors in performing their duties to serve clients who are carried out for making a decision. The variable of professionalism is measured using eight questions that describe dedication to the profession, social obligations, independence, belief in the profession and relationships among professions.

Emotional Intelligence

Emotional intelligence describes the attitude of the ability to feel, understand effectively to apply power and emotional sensitivity as a source of human energy, information, connections and influence. The emotional intelligence variable is measured using eight questions that describe self-awareness, innovation, optimism, drive for achievement, understanding others, communication skills.

Audit Quality

Audit quality is defined as the probability that an auditor finds out that there is a violation in his client's financial statements and reports it. The variables are measured using six questions that describe conformity with audit standards, misstatement detection, compliance with audit procedures, audit risk, and precautionary principles.

\section{Data analysis method}

\section{Data Quality Test}

Test data quality is used to test the seriousness or suitability of respondents in answering the questionnaire will greatly determine the quality of data collected by testing the validity and reliability. 
Classic assumption test

The analytical tool used in this research is moderation regression analysis. The classic assumption test is used to test the statistical assumptions that must be fulfilled so that the data entered in the regression model has met the terms and conditions in the regression. The classic assumption test in this study includes the normality test, multicolonierity test, heteroscedasticity test and autocorrelation test.

Multiple Linear Regression Analysis

Multiple linear regression analysis is an analysis used to measure the effect of independent variables on the dependent variable. (Ghozali, 2014:219). The formulation of the multiple linear regression model used is:

\section{$Y=a+\beta_{1} X_{1}+\beta_{2} X_{2}+\beta_{3} X_{3}+\beta_{4} X_{4}+e$}

\section{Moderated Regression Analysis (MRA)}

The moderating variable is the independent variable that serves to strengthen or weaken the relationship between the independent variables and the dependent variable. Moderated Regression Analysis (MRA) or interaction test is a regression equation that contains interaction elements (multiplication of two or more independent variables) with the following equation: $\mathrm{Y}=\mathrm{a}+\mathrm{b} 1 \mathrm{X} 1$ Equation (I) $\mathrm{Y}=\mathrm{a}+\mathrm{b} 1 \mathrm{X} 1+\mathrm{b} 2 \mathrm{X} 2+\mathrm{b} 3 \mathrm{X} 1 \mathrm{X} 2+\mathrm{e}$ Equation (II) Description: Y: Audit Quality a: Constants b: Multiple Regression Coefficient X1, X2, X3: Independent Variables

\section{Hypothesis test}

Coefficient of Determination (R2)

The coefficient of determination in essence measures how far the model's ability to explain the variation in the dependent variable. The coefficient of determination is between zero and one. The small value of R2 means that the ability of the independent variables to explain the variation of the dependent variable is very independent. A value close to one means that the dependent variables have almost all the information needed to predict the variation in the dependent variable. 
T statistical test (significant test for individual parameters)

The $t$ test is a partial test of the regression coefficient. This test is conducted to test the partial significance of the dependent variable on the independent variable by assuming that other independent variables are considered constant.

1) If $t$-count $<t$-table, then the independent variable individually has no effect on the dependent variable (H0 is accepted).

2) If $t$-count $>t$-table, then the independent variable individually affects the dependent variable (H0 is rejected).

\section{RESULT AND DISCUSSION}

\section{Data Quality Test}

Based on the results of the calculation, it is obtained a significant value of 0.000 on all items of the variable statements $\mathrm{X} 1, \mathrm{X} 2, \mathrm{X} 3, \mathrm{X} 4, \mathrm{Z}$ and $\mathrm{Y}$. If the sig value $<0.05$, the instrument can be said to be valid. So that these results indicate that all statement items in each variable are valid. While the reliability test used in this study is to use the Alpha-Cronbach coefficient. If the alpha value is more than $>0.60$ in a variable (construct), the reliability level of the instrument measurement is getting better or perfect. Based on the calculation, it is obtained that the AlphaCronbach value for variable $\mathrm{X} 1$ is 0.803 , variable $\mathrm{X} 2$ is 0.782 , variable $\mathrm{X} 3$ is 0.780 , variable $\mathrm{X} 4$ is 0.786 , variable $\mathrm{Z}$ is 0.790 and variable $\mathrm{Y}$ is 0.791 . Alpha-Cronbach value of each variable> 0.60 which means that the variables used in this study are reliable.

\section{Classic assumption test}

Normality test

Based on the table shows that the Kolmogorov Smirnov value of

0.845 with a significance level far above 0.05 , namely 0.472 , which means that the residual value of the regression equation used in this study is normally distributed. This shows that the regression model in this study is suitable for use because it has met the classic assumptions of resediual normality.

\section{Multicollinearity Test}

Based on the table above, it shows that the competency variable has a tolerance value of 0.358 and a VIF value of 2.790. The independence variable has a tolerance value of 0.446 and a VIF 
value of 2.244. The Auditor Ethics variable has a tolerance value of 0.375 and a VIF value of 2.667, and the Professionalism variable has a tolerance value of 0.425 and a VIF value of 2.352. So it can be concluded that there is no multicollinearity between independent variables in the regression model.

Heteroscedasticity Test

Based on the picture above shows that the dots spread randomly and are spread above and below the number 0 on the $\mathrm{Y}$ axis. It can be concluded that there is no heteroscedasticity so that the regression model is feasible to use.

Multiple Linear Regression Analysis

Regression analysis is used to measure the effect of the independent variable (independent) on the dependent variable (dependent). Where the regression results can be seen as follows:

Table1. Multiple Regression Results

\begin{tabular}{|l|r|r|r|r|r|}
\hline \multirow{2}{*}{ Model } & \multicolumn{2}{|c|}{$\begin{array}{c}\text { Unstandardized } \\
\text { coefficients }\end{array}$} & \multicolumn{1}{c|}{$\begin{array}{c}\text { Standardized } \\
\text { coeffisients }\end{array}$} & \multirow{2}{*}{$\mathrm{t}$} & \multirow{2}{*}{ Sig. } \\
\cline { 2 - 4 } & \multicolumn{1}{|c|}{$\mathrm{B}$} & \multicolumn{1}{c|}{ Std. Eror } & \multicolumn{1}{c|}{ Beta } & & \\
\hline (Constant) & 14.565 & 3.624 & & 4.019 & 0 \\
\hline Kompetensi (x1) & -0.124 & 0.169 & -0.122 & -0.736 & 0.464 \\
\hline Independensi (x2) & 0.646 & 0.15 & 0.638 & 4.291 & 0.000 \\
\hline Etika auditor (x3) & -0.04 & 0.185 & -0.035 & -0.217 & 0.829 \\
\hline $\begin{array}{l}\text { Professionalisme } \\
\text { (x4) }\end{array}$ & -0.026 & 0.137 & -0.029 & -0.189 & 0.85 \\
\hline
\end{tabular}

Source: Output SPSS

The regression line equation obtained is as follows:

$Y=14.565-0.124 \times 1+0.646 \times 2-0.04 \times 3-0.026 \times 4$

From the above equation, it is obtained:

a. A constant value of 14,565 indicates that if the independent variables, namely competence, independence, auditor ethics and professionalism do not exist, then the audit quality value is a constant of 14.565 .

b. The competency coefficient of -0.124 indicates that each one unit increase in competence will result in a decrease in audit quality of -0.124 units. The value of the $\beta$ coefficient of the competency variable is negative, namely -0.124 . 
c. The independence coefficient of 0.646 indicates that each increase in the independence of one unit will result in an increase in audit quality of 0.646 units. The value of the $\beta$ coefficient of the independence variable is positive, namely 0.646 .

d. The auditor ethics coefficient of -0.04 indicates that each one-unit increase in competence will result in continued audit quality of -0.04 units. The $\beta$ coefficient value of the competency variable is negative, namely -0.04 .

e. The competency coefficient of -0.026 indicates that each one-unit increase in competence will result in a decrease in audit quality by -0.026 units. The value of the $\beta$ coefficient of the competency variable is negative, namely -0.026 .

Moderated Regression Analysis (MRA)

Table2. Results of Regression Equations I

\section{Model Summary}

\begin{tabular}{|c|c|c|c|c|}
\hline Model & $\mathrm{R}$ & R Square & $\begin{array}{l}\text { Adjusted R } \\
\text { Square }\end{array}$ & $\begin{array}{l}\text { Std. Error of the } \\
\text { Estimate }\end{array}$ \\
\hline 1 & $.557^{\mathrm{a}}$ & .310 & .271 & 2.554 \\
\hline
\end{tabular}

a. Predictors: (Constant), $x 4, \times 3, \times 2, x 1$

Table3. Results of Regression Equations II

Model Summary

\begin{tabular}{|c|c|c|c|c|}
\hline Mode & $\mathrm{R}$ & R Square & $\begin{array}{l}\text { Adjusted R } \\
\text { Square }\end{array}$ & $\begin{array}{l}\text { Std. Error of the } \\
\text { Estimate }\end{array}$ \\
\hline 1 & $.799^{\mathrm{a}}$ & .639 & .589 & 1.918 \\
\hline
\end{tabular}

a. Predictors: (Constant), x4, $z, x 3, x 2, x 1, x 4 \_z, x 3 \_z, x 2 \_z, x 1 \_z$

The R2 value in the first regression was 0.271 or $27 \%$, while with the moderating variable emotional intelligence, the R2 value increased to 0.589 or $59 \%$. By looking at the results above, it can be concluded that the existence of the Emotional Intelligence variable (moderating variable) can strengthen the relationship between competence, independence, auditor ethics, and professionalism on audit quality. 


\section{Hypothesis testing}

\section{Determination Coefficient Test $\left(\mathrm{R}^{2}\right)$}

The coefficient of determination (R2) essentially measures how far the independent variable model is able to explain the variation in the dependent variable. From the analysis results can be presented as follows.

Table4. Coefficient of Determination $\left(\mathrm{R}^{2}\right)$

\begin{tabular}{|r|r|r|r|}
\hline Model & R Square & \multicolumn{1}{|c|}{$\begin{array}{c}\text { Adjusted R } \\
\text { Square }\end{array}$} & Std. Eror of the Estimate \\
\hline 1 & $.557^{\mathrm{a}}$ & 0.271 & 0.271 \\
\hline
\end{tabular}

Based on the table above, the value of determination coefficient (adjusted $\mathrm{R}^{2}$ ) is 0.271 or $27 \%$, this means that the variables of Competence, Independence, Auditor Ethics and Professionalism on Audit Quality are 27\%. And 73

$\%$ influenced by other variables outside the research model.

\section{Statistical Test F}

The results show that the calculated $F$ value of 7.870 while the $F$ table of 2.50 is obtained from df1 with the k-1 formula of 4 and df 2 with the $n-k$ formula of 70 where $n$ is the number of samples and $\mathrm{k}$ is the number of variables used. $\mathrm{F}$ count $>\mathrm{F}$ table with a value of 7.870>2.50 and a sig value of $5 \%=0.05$, which means that the five independent variables simultaneously have a significant effect on audit quality.

Table5. Statistical Test F

\begin{tabular}{|c|c|c|c|c|c|c|}
\hline \multicolumn{7}{|c|}{ ANOVA $^{a}$} \\
\hline \multicolumn{2}{|c|}{ Model } & Sum of Squares & df & Mean Square & $\mathrm{F}$ & Sig. \\
\hline \multirow[t]{3}{*}{1} & Regression & \begin{tabular}{|l|}
205.354 \\
\end{tabular} & 4 & 51.338 & 7.870 & $.000^{b}$ \\
\hline & Residual & 456.646 & 70 & 6.524 & & \\
\hline & Total & 662.000 & 74 & & & \\
\hline
\end{tabular}

\section{Test Statistic T}

From the results of testing the equation above, it can be concluded that: 
1. The $t$ value of Competence (X1) - 0.736 with a probability of 0.464 .

While the t-table value is 1.66691 , so $t$ count $<\mathrm{t}$ table $(-0.736<$

1.66691). This shows that competence (X1) partially has no effect on audit quality. So that H1 is accepted

2. The $t$ value of Independence (X2) is 4.291 with a probability of 0.000 .

While the $t$-table value is 1.66691 , so that $t$ count $>t$ table $(4.291>1.66691)$. This shows that independence (X2) partially has a positive and significant effect on audit quality. So that $\mathrm{H} 2$ is rejected.

3. The t value of the Auditor Ethics (X3) - 0.217 with a probability of 0.829 .

While the t-table value is 1.66691 , so $t$ count $<\mathrm{t}$ table $(-0.217<1.66691)$. This indicates that the Auditor Ethics (X3) partially has no effect on audit quality. So that H3 is accepted.

4. The $t$ value of professionalism (X4) -0.189 with a probability of 0.85 .

While the t-table value is 1.66691 , so $t$ count $<\mathrm{t}$ table $(-0.189<$

1.66691). This shows that professionalism (X4) partially has no influence on audit quality. So that $\mathrm{H} 4$ is accepted.

\section{INTREPETATION}

\section{The Effect of Competence on Audit Quality}

Based on the research results, it was found that competence had no effect on audit quality. This can be proven by the coefficient value of -0.124 , which means that each one-unit increase in competence will result in a decrease in audit quality of -0.124 units. Meanwhile, from the results of research through the $t$ test it is known that the auditor's competence partially has no effect on audit quality. It can be shown that competence has t count $<$ t table $(-0.736<1.66691)$ with a significance level of 0.464 .

$<0.05$. So competence on audit quality has no effect. (Ha accepted).

According to De Angelo (1981: 118) in Sholawatun (2015) competence is proxied into knowledge and experience. To perform auditing duties, auditors need auditing knowledge (general and specific) and knowledge of the areas of auditing, accounting and the client industry. Besides that, experience is also needed in conducting audits. This research is supported by the results of research conducted by Carolita and Rahardjo (2012) and Wardoyo et al., (2011) who found that competence does not have a significant effect on the quality of audit results. Research conducted by Carolita and Rahardjo (2012) and Wardoyo et al., (2011) proxies competency 
variables in two ways, namely knowledge and experience which do not always affect audit quality.

\section{The Effect of Independence on Audit Quality}

Based on the research results, it is found that independence has a positive effect on audit quality. This can be proven by the coefficient value of 0.646 which means that every increase in the Independence of one unit will result in an audit quality of 0.646 units. Meanwhile, from the results of research through the $t$ test it is known that the competence of auditors partially has a positive effect on audit quality. This can be shown that the independence has $t$ count $<\mathrm{t}$ table (4.291> 1.66691) with a significance level of 0.000

$<0.05$. So independence has an effect on audit quality. (Ha rejected).

This research is supported by the results of previous research by Dwiyanti (2010) that independence affects audit quality. An audit is said to be of quality if the results are able to make the users make the right decisions. Auditor independence is needed so that auditors are not easily influenced by certain parties who want to take advantage of themselves. An independent auditor will also report all detection errors found during the audit, make appropriate

judgments without being influenced by any party, so that the auditor can prove the validity of the numbers presented and report in accordance with reality. In line with the research results of Rahman (2009), it shows that independence has an effect on audit quality. An independent auditor will provide a real assessment of the financial statements, without any burden on any party, so that the resulting assessment will reflect the actual conditions of the client being examined.

\section{The Effect of Auditor Ethics on Audit Quality}

Based on the research results, it was found that Auditor Ethics had no effect on audit quality. This can be proven by the coefficient value of -0.04 , which means that each one unit increase in Auditor Ethics will result in a decrease in audit quality by -0.04 units. Meanwhile, from the results of research through the $t$ test it is known that the ethics of auditors are not partially affect audit quality. It can be shown that competence has t count $<\mathrm{t}$ table $(-0.217<1.66691)$ with a significance level of $0.829<0.05$. So Auditor Ethics on audit quality has no effect. (Ha accepted).

However, this research is contrary to the research conducted by

Titin Rahayu (2016) states that the Auditor Ethics variable has a t-count of 
2.467 and a significant level of $0.017<0.05$, which means that auditor ethics has a significant and significant effect on audit quality. So that auditors with better ethics will get better audit quality, therefore to improve the performance of an auditor, auditors are required to maintain ethical standards of behavior in order to be able to produce quality audits.

According to Prof. Dr. Abdul Halim (2015: 21) The principles of professional ethics in the code of ethics in the Indonesian Accountants Association state that professional recognition of its responsibilities to the public, accountants, and colleagues. This principle integrates members in fulfilling their professional responsibilities and forms the basis of ethical behavior and professional behavior. This principle calls for a commitment to behave respectfully, even at the cost of personal gain.

\section{The Effect of Professionalism on Audit Quality}

Based on the research results, it is found that professionalism has no effect on audit quality. This can be proven by the coefficient value of -0.026 , which means that every one unit increase in professionalism will result in a decrease in audit quality of -0.026 units. Meanwhile, from the results of research through the $t$ test it is known that professionalism is partially

has no effect on audit quality. It can be shown that competence has t count <t table $(-0.189$ $<1.66691$ ) with a significance level of 0.85 .

$<0.05$. So professionalism on audit quality has no effect. (Ha be accepted).

This study is supported by the results of research by Putu Septiani (2014) that professionalism has no effect on audit quality with a significant level of 0.057>0.05.

Thus professionalism needs to be improved, because it is very important in conducting an inspection so that it will have an influence on the quality of the audit. The expectations of the 
community for the demands for transparency and accountability will be fulfilled if the auditors can carry out professionalism well so that the public can assess the quality of the audit.

5. The Effect of Competence, Independence, Auditor Ethics and Professionalism on Audit Quality with Emotional Intelligence as a Moderation Variable.

Based on the results of the study, it was found that the R2 value in the first regression was 0.310 or $31 \%$, while after the second regression equation the $\mathrm{R} 2$ value rose to 0.634 or $63.4 \%$. By looking at the results above, it can be concluded that the existence of the Emotional Intelligence variable (moderating variable) can strengthen the relationship between Competence, Independence, Auditor Ethics, and Professionalism on Audit Quality.

This research is supported by Sholawatun (2015) that emotional intelligence strengthens the relationship between competency, independence, auditor ethics and professionalism on audit quality. An auditor who has an empathetic attitude so that he can be more responsive to the needs of his clients and will always motivate himself to be committed to audit quality. Emotional intelligence makes auditors skilled in communicating so that they can obtain information that makes them better understand the conditions of their client companies. Better understanding will make auditors make good audit decisions.

\section{CONCLUSION}

The conclusion from the results of this study is that the results of the study indicate that the independent variable has a partial effect on audit quality, while the variables of competence, auditor ethics and professionalism on audit quality do not have a partial effect. Meanwhile, competency, independence, auditor ethics and professionalism variables simultaneously influence audit quality. The results of the study indicate that the Emotional Intelligence moderating variable can strengthen the relationship between competence, independence, auditor ethics and professionalism on audit quality.

The results of research on the influence of Competence, Independence, Auditor Ethics and Professionalism on Audit Quality with Emotional Intelligence as a Moderation Variable. It shows that Competence, Independence, Auditor Ethics and Professionalism have no effect and are not significant towards Audit Quality. The implication is that an auditor should improve 
competence, auditor ethics and professionalism in order to produce a better audit quality and be able to be trusted for his services as a high quality auditor.

\section{REFERENCES}

Agustin, Restu Dan Pertiwi, Putrid. 2013. Pengaruh Kompetensi, Independensi Dan Profesionalisme Terhadap Kualitas Audit (Studi Empiris Pada Kantor Akuntan Publik Se Sumatera). Jurnal Ekonomi, Volume 21, Nomor 3.

Arens, A Alvin, Elder, Randal, J dan Beasley, Mark S. 2012. Auditing dan jasa Assurance. 2008. Edisi kedua belas, jilid 1. Penerbit Erlangga.

Asih, Retno. 2010. Pengaruh Batasan Waktu Audit, Pengetahuan Dan Pengalaman Auditor Terhadap Kualitas Audit Pada Kantor Akuntansi Publik (KAP) Di Surabaya. Skripsi. Stie mandala jember

Ayuningtyas, Harvita Yulian Dan Pamudji, Sugeng. 2012. Pengaruh Pengalaman Kerja, Independensi, Objektivitas, Integritas Dan Kompetensi Terhadap Kualitas Audit. (Studi Kasus Pada Inspektorat Kota/Kabupaten Di Jawa Tengah). Diponegoro. Journal Of Accounting. Volume 1 (2) : 1-10

Carolita, Metha Kartika Dan Rahardjo, Shiiddiq Nur. 2012. Pengaruh Pengalaman Kerja, Independensi, Objektifitas, Integritas, Kompetensi Dan Koitmen Organisasi Terhadap Kualitas Hasil Audit (Studi Pada Kantor Akuntan Publik Di Semarang). Diponegoro. Journal Of Accounting. Volume 1 (2) : 1-11.

De Angelo, LE. 1981. Auditor Independence, Low Balling, And Disclosure Regulation. Journal Of Accounting And Economics 3 Agust P 113-127.

Dwijayanti, Aini Alfiyah. 2010. Pengaruh Kompetensi Dan Independensi Terhadap Kualitas Audit Dengan Kecerdasan Emosional Sebagai Variabel Moderasi. Skripsi. Fakultas Ekonomi Universitas Airlangga. Surabaya.

Darayasa, I made dan Wisadha, I Gede Supartha. 2016. Etika Auditor Sebagai Pemoderasi Pengaruh Kompetensi Dan Independensi Pada Kualitas Audit Di Kota Denpasar. EJurnal Akuntansi Universitas Udayana. Volume 15.1, Nomor 142-170.

Elfarani, Eunike Christina. 2007. Pengaruh Kompetensi Dan Independensi Auditor Terhadap Kualitas Audit. Skripsi. Universitas Negeri Semarang. 
ABM : International Journal of Administration, Business and Management, Vol. 1 No. 1 November 2019

Futri, Putu Septiani Dan Juliarsa,Gede. 2014. Pengaruh Independensi, Profesionalisme, Tingkat Pendidikan, Etika Profesi, Pengalaman Dan Kepuasan Kerja Auditor Pada Kualitas Audit Kantor Akuntan Publik Di Bali. E-Jurnal Akuntansi Universitas Udayana, Volume 7, Nomor 2.

Ghozali, Imam. 2014. Aplikasi Analisis Multivariate Dengan Program Spss. Semarang. Universitas Diponegoro.

Http://.www.ojk.go.id/id. Diakses bulan desember 2016 